\section{INCZE Emma}

\section{A VÁLLALATOK \\ NEMZETKÖZIESEDÉSÉNEK DINAMIKÁJA}

\section{- EGY KUTATÁSI MODELL} A tanulmány a nemzetköziesedés elméleti modelljeinek hiányosságaival szembesülve amellett érvel, hogy
ahhoz, hogy megértsük a nemzetköziesedés idóben zajló folyamatát, a vállalatok nemzetközi evolúcióját a kontextussal összefüggésben kell vizsgálni. A tanulmány a vállalatok nemzetköziesedésének folyamatát vizsgáló elméleti szakirodalomra építve egy olyan kutatási modelt vázol fel, amely alkalmas lehet a nemzetköziesedés dinamikájának empirikus vizsgálatához. A modell a belépés, diverzitás, ütem és szakasz nemzetköziesedés dinamikajanak empirikus vizsgálatához. A modell a belépés, diverzitás, ütem és szakasz koncepciók mentén operacionalizált nemzetköziesedés mintázata és a kontextus (környezet, vállalat, menedzsment) közötti kapcsolatot teremti meg. A vázolt kutatási modell empirikus alkalmazásával lehetốvé Kulcsszavak: nemzetköziesedés, kutatási modell

A vállalatok nemzetközi tevékenységének vizsgálatával a nemzetközi üzleti gazdaságtan foglalkozik és kōzel egy fél évszázada foglalkoztatja a témában érdekelt kutatókat. A terület gyökereit a nemzetközi gazdaság$\tan ^{1}$ képezi. Egészen az 1960-as évekig a közvetlen külföldi tókebefektetésekre mint múködótóke-mozgások tokintettek, és a nemzetközi kereskedelmet is azasok ok kome es a orszagok konpar eveken Stephen Hymer (1960), Charles Kindleberg (1969), Edeperosen (1966) úttöró munkái hívták fel a figyelmet a vállalatra,min nemzeti határokat átszelő entitásra.

A nemzetközi üzleti gazdaságtan a diszciplínák széles körére épít, következésképpen nagyfokú diverzitás jellemzi az elméleti és empirikus irodalmat egyarán A különböző elméletek, modellek és specifikus témakörök négy fő́ csoportba sorolhatók ${ }^{2}$ :

a makrogazdasági irányultságú, határokon átnyúló tókeáramlások elméletei ${ }^{3}$,

a multinacionális vállalatok létezésének közgazdasági elméletei, modelljei ${ }^{4}$,

a vállalatok nemzetköziesedésének modelljei,

a multinacionális vállalatok vezetésének és szervezésének modelljei (melyet gyakran nemzetköz menedzsment megnevezessel illetnek).
A határokon átnyúló tốkeáramlások, a multinacionális vâllalatok létezése és a nemzetközi menedzsment elméleti irodalma érettségét tekintve elôrébb jár, mint a nemzetköziesedés szakirodalma. Ez részben annak tulajdonítható, hogy a vállalati magatartás folyamatszemléletú vizsǵlata idóigényesebb longitudinális módszertant követel.

E tanulmány a vállalatok nemzetköziesedésének foJyamatát vizsgáló elméleti szakirodalomra építve egy olyan kutatási modellt vázol fel, amely alkalmas lehet a nemzetköziesedés dinamikájának empirikus vizsgálatához.

A nemzetköziesedés szakirodalmi értelmezése és elméleti modelljei ${ }^{6}$

A szakirodalomban leggyakrabban Welch és Luostarinen definíciójával találkozhatunk, mely szerint a nemzetköziesedés a nemzetközi kötelezettségvállalás fokozatos növekedését jelenti (Welch-Luostarinen, 1988). Szerintük a nemzetköziesedés egy két irányba mutató a külföldi felé, azaz kifelé mutató irányba (outward) nemzetköziesedhetnek, hanem befele is (inward), azaz külföldi partnerekkel köthetnek tranzakciókat a belföldön végzett tevékenységhez ${ }^{7}$, sôt kedvező́tlen körülmények folyamat, azaz a vállalatok nemcsak a belföldi piacról vagy stratégiai megfontolás hatására vissza is vonhatják nemzetközi tevékenységüket (de-internationalization) (Welch - Luostarinen, 1993). Egy másik definíció szerint a nemzetköziesedés egy stratégiai folyamat (Melin, 1992) - melynek során a vállalat perspektívát és pozíció vált (Mintzberg, 1987), és a vállalatok külföldi földrajzi diverzifikációjával áll szoros kapcsolatban. A legáltalánosabb definíciót Beamish (1990) fogalmazta meg, mely szerint a nemzetköziesedés egy olyan folyamat, amelynek során a vállalatok figyelmüket a nemzetközi tranzakcióknak a vállalat jövơjét érintố közvetlen es közvetett hatásár folytatnak más országok vállalataival.

A vállalatok nemzetköziesedésének folyamatát magyarázó elméleti modellek gyökerei Cyert és March (1963) vállalati magatartás elméletében, valamin Penrose (1959) vállalatnövekedési elméletében talá hatók. A nemzetköziesedés alapvetố modellje a hoszszú múltra visszatekintő nemzetköziesedési folyam modell (Internationalization Process Model), vagy más nevén az Uppsala-modell (Johanson - Vahlne, 1977, 1990). Az 1977-ben megalkotott modell szerint a nemzetköziesedés legfő́bb mozgatórugója a nemzetköziesedéshez szükséges tudás, amely legfốképp nemzetközi piaci tapasztalat útján szerezhetố meg. Tekintve, hogy a tapasztalatszerzés idóbe telik, a nemzetköziesedés egy inkrén növeked" pici elkötelezóst növekedó piaci elk folyamar. A szerzok, felismorven a kontextus, az gyakorlat változásanak számottevố hatását, valamint hálózatok és a vallalkozói nézópont (entrepreneurship) jelentőségteljes elméleti fejlő́dését, a későbbiekben ujjrafogalmazták a modellt (Johanson - Vahlne, 2009). A nemzetköziesedés mechanizmusa ugyanaz marad, mint a régi modellben, azaz továbbra is egy tanulási folyamatnak tekinthető, ugyanakkor a nemzetköziesedéshez szükséges tudás fogalmát az újragondolt modellben a szerző́k kiegészítették a lehetôség felismerésének fogalmával, amely napjainkra a nemzetköziesedésben is szerepet játszó vállalati tudás legfontosabb elemévé vált A piaci elkötelezôdés helyett a hatúrokon útmé

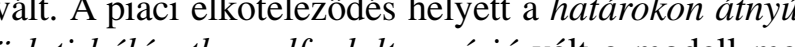
uzleti haluzabon elfoglat pozicio valt a modell meghatározó dimazion rint a nenzetköziesedés a úzlei halozatokban rejló lehetöségek felismerésének és kiaknazasának folyamata. A nemzenoziesedes bizonytalansa kas kisebb nértekben tulajdonítható az eredeti modellben pszichikai távolságnak nevezett tényezonnek, mint az ujabb modell szerin releváns üzleti hálózaton kivüliségnek (outsidership).

A vállalkozôi irányultságú nézet (intenation entrepreneurship) (pl. Covin - Slevin, 1991; Zahra, 1993; Lumpkin - Dess, 1996; Brazeal - Herbert, 1999;
Shane - Venkataraman, 2000; Zahra et al., 2005; Jones Coviello, 2005) a vállalatok nemzetköziesedésének gyy újabb megközelítése. E nézópont alkalmazása a vállalatok nemzetköziesedésének magyarázatára még kevéssé kiforrott, de jelentôsége egyre nōvekszik, föként a kis- és közepes méretú, dinamikus vállalatok esetében. A tradicionális Uppsala-modelltól eltérően, amely azt feltételezi, hogy a vállalatok először a hazai piacon erősödnek meg, és csak utána lépnek külföldi piacra, a vállalkozói irányultságú nézet szerint a vállalatok szïletésïktól fogva ágy tekintenek a világra min hetséges piacra (McDougall et al, 2003). Proaktív

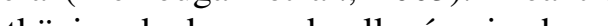
móc éch fogva kilok grva a különbözó országokban elérhetó eróforrásokat veszik igénybe, és különbözó külföldi piacokon értékesítik termékeiket vagy szolgáltatásaikat. E képesség elôfeltétele a különbözó piacokhoz való dinamikus alkalmazkodás, a lehetốségek felismerése és a kombinációs képesség. A külföldi közvetlen tốkebefektetés helyett gyakran a nemzetközi stratégiai szövetségek különböző formáit részesítik előnyben, melynek révén gyorsan hozzájutnak a külföldi erőforrásokhoz, mint például gyártókapacitáshoz vagy marketingismerethez Oviatt - McDougall, 1994)

A nemzetközi vállalkozói magatartás megragadáa érdekében Jones és Coviello (2005) megalkotta a nemzetköziesedés vállalkozói modelljét. A szerzók úgy kintenek a nemzetköziesedésre, mint egy folyamatos fejlódési és változási folyamatra, mint egy hosszú távú vállalkozói magatartást jelző jelenségre, amely sajátos mintázatot vehet fel az egyes vállalatok esetében, ezért nem jeleznek elore semmifele evolúciós utat. Modelljük egyik legfontosabb eleme az idó, melyet számos dimenzióban értelmeznek, különböző fogalmakkal élve, mint például kronológiai idô, a nemzetköziesedési esemény létrejöttét jelző referenciaidő, periódus, sorozat, idôtartam, idóintenzitás, ciklikusság, sebesség. A modell három fajta nemzetköziesedési eseményt kïlönböztet meg.

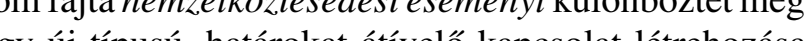
n létrehozott kapcsolat, valamint egy kapcsolat megszúnése. A nemzetköziesedés új enyomatának nevezi az egy adott idốpontban jellemzó módozatok számát és választékát, valamint az országok zzámát és távolságát. A nemzetkōziesedés dinamikus profilját a módozatok és országok összetételének időbeni változásai adják. A nemzetköziesedés kontextuális tényezói a teljesítmény, a vállalat, a vállalat környezete, valamint a vállalkozó(k), amelyek további alváltozókat oglalnak magukba, mint a teljesítmény pénzügyi és nem pénzügyi mércéi, vállalati struktúra, erơforrások, 
termékek, vállalkozói orientáltság, piaci és iparági jellemzók, valamint a vállalkozó(k) világnézete, szociális és humán tốkéje.

A fentiekben összefoglalt, a cégek nemzetköz esedésével foglalkozó szakirodalom kimondatlanul idôhöz kötött folyamatként tekint a nemzetköziesedésre, függetlenül attól, hogy fokozatos tanulási folyamatkén (pl. Johanson - Vahlne, 1977; Welch - Luostarinen, 1988) vagy gyorsan végbemenố vállalkozói folyamatként (Oviatt - McDougall, 1994) határozza meg azt. Ugyanakkor számos, az idônek a nemzetköziesedés di-

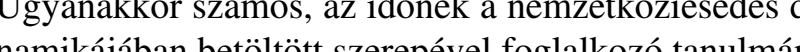
namikajaban betoiost szerepével foglalkozó tanulmány látott napvilágot (e.g. Covicllo-Munro, 1997; Kutschke Jones - Coviello, 2002, 2005; Hurmerinta-Peltomäki, Jones -Coviello, 2002, 2005; Hurnerinta-Peltomaki, 2003, Hashai - Almor, 2004). E tanulmányokban hangsúly a nemzetköziesedés idóalapú, processzuál so szemléletére (Malnight, 1995), a nemzetközi vállalat vezetésének idốbeni alakulására (Kutschker et al., 1997), a nemzetközivé válás vállalkozói folyamatának kronológiai vizsgálatára (Jones - Coviello, 2002, 2005) helyeződik. Valamennyi tanulmány a nemzetköziesedés dinamikáját helyezi előtérbe az idő dimenziójának figyelembevételével. A nemzetközi üzleti koncepciók és elméletek mellett ezek a tanulmányok a szervezeti folyamatelméletekben gyökerezô elméleti és empirik foncepciókra építenek, mint az ingóció és víltozas koncepción - éter, 1990; Va in de Ver Van de Ven - Engleman, 2004).

\section{A nemzetköziesedés folyamatának}

újrafogalmazása

Annak ellenére, hogy a nemzetközivé válás folyam tának megértéséhez és bemutatásához igen fontos fejlő́dés idörendben történó vizsgálata, még mindig hiányoznak azok a tanulmányok, melyek egy ado időszakban megtörtént események sorrendjét és öszszefüggéseit tárgyalják. A tanulmányok legtöbbjébe sor kerïl a nemzetközivé válás mintájának idören ben történó megrajzoláśn ben torttenó megrajzolására, azonban magának a folyamatnak a vizsgálata elmarad. Ennek oka, hogy nemzetköziesedéssel foglalkozó kutatások a folyama fogalmanak szúk ertelmezesére építenek. A továbbiakban a szervezetelméleti kutatásokban fellelhetö folyamatkoncepciókat mutatjuk be, amelyekre támaszkodv újrafogalmazható a nemzetköziesedés folyamatána koncepciója.

A szervezetelméleti tanulmányokban a folyama koncepciójának két alapvetố felfogása jelenik meg "gyenge” és az „erôs”, amelyek részben átfedik egymást, mégis különböznek (Chia - Langley, 2004; Van de Ven - Poole, 2005). A „gyenge” felfogás a folyamatokat ,dolgok” alakulásaként szemléli, melyek változóként vagy állapotokként írhatóak le és hasonlíthatók össze, míg az „erôs” szemlélet a tevékenységekre és dolgokra úgy tekint, mint ,folyamatkomplexumokra” Chia - Langley, 2004). A szervezeti kutatásokban rendszerint az elsố felfogás jelenik meg, ami a nagyobb fokú gyakorlatiasságnak, az empirikus megalapozottságnak és elemzó jellegnek kedvez. A második perspektíva elsősorban koncepcionális jellegú, és a dinamikus fogalmak mint például események, eredmények sorrend, váloź́s, kapesoltok, mintázatok, profilok és kïlö különbó zónt kontextualis kategoriák a szervezeti élet lényegeként jelennek meg (pl. Langley, 1999). Miközben az elsó felfogás segítseget nyujt a folyamatok megfigyeléséhez es tapasztalati alapon tơrtenô vizsgálatához, addig az utóbbi lehetốvé teszi a sui generis megértését Az első felfogás a pozitivista kutatási filozófiában gyökerezik, a magyarázat végső célját szem előtt tartva, a második pedig az interpretatív megközelítésben, a leírás és megértés célkitűzésével.

A legtöbb nemzetközi gazdaságtani kutatással kapcsolatos tanulmány a „gyenge” folyamatfelfogással jellemezhetó pozitivista irányvonalat képviseli. Az interpretatív kutatási filozófia általában kívül esik a nemzetközi gazdaśatan és nemzetközi menedzsmentel foglalkoź kuták figyelmén ́́ ́ndeklódéśn.

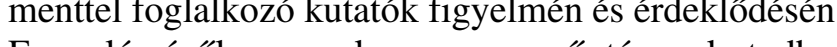
tó be, vaszinuleg annak az egyszerú ténynek tudható be, hogy a "magyarázat elengedhetetlen az elmélet és a gyakorlat számára" (Pentland, 1999: 711. o.). A nemzetközi gazdaságtan kutatásának úgynevezett „szúk látóköre” (Sullivan, 1998) ugyanakkor szélesedett a multidiszciplináris megközelítési módoknak és a folyamatorientáltabb kutatási módszereknek köszönhetôen. E törekvés újabb keletư példája az előzőekben bemutatott nemzetköziesedés vállalkozói nézetének általános modellje (Jones - Coviello, 2005). Ez egy fogalmi modell, amely integrálja a már létezô pozitivista modelleket, kiemelt figyelmet szentelve az idót magában foglaló koncepcióknak. A modell megele(1) . vagy az "erôs "folyamatfelfogást képviseli-e. A nemzetközivé válást idóben elhelyezve tárgyalja, azonban a nemzetkoziesedés ,története" „dolgokra" korlátozódik. Pontosabban: elöre kiválasztott változókra, mint a szervezeti struktúra és szervezeti erőforrások, múködési környezet jellemzói, teljesítményjellemzók és így tovább (Jones - Coviello, 2005: 296. o.). A modell felfedi a nemzetköziesedés input és output változói közötti kapcsolatot, de semmit nem árul el az összefüggést mutató változók sorrendjéról és változásáról, melyek a

nemzetköziesedés eseményeihez vezetnek. Azonban, ahogy Pettigrew (1990: 269. o.) megállapította, ,....az elméletileg helytálló és gyakorlati szempontból hasznos, változással kapcsolatos kutatásoknak meg kell világítaniuk a változás tartalmát és folyamatát ezek idóben elhelyezett kapcsolódásaival együtt". A Jone és Coviello modell (Jones - Coviello, 2005) összeköti a változás tartalmát a kontextusával, azonban az utóbbit statikus dimenzióként kezeli, ennélfogva a modell a „gyenge” folyamatfelfogást képviseli.

A fenti elméleti érvelés alapján a vállalatok nemzetköziesedésére vonatkozóan az alábbi propozíció (P) fogalmazható meg:

P1: A nemzetköziesedés dinamikájának hátterében állo okok teljes megértése érdekében az akciók és interakciók, valamint ezek idóbeni alakulását szükséges vizsgálni, egy folyamatábrázoló modell segítségével.

A folyamatelméleti filozófusok, mint Henri Bergson, William James és Alfred North Whitehead múvei alapján, a folyamat-metafizika általában a valóság fejlő́dó természetének feltárására törekszik, a statikus létezéssel vagy léttel szemben az átalakulâst hangsúlyozva (Center for Process Studies, 2007). Továbbá k emeli a valamennyi entitás között fennálló kölcsönö kapcsolatot. Szervezetelméleti tudósok - Van de Ven és Poole - a folyamatot események sorozataként határozzák meg, leírva, hogy a dolgok idóvel miképpen változnak (Van de Ven - Poole, 2005). Ennek megfelelóen egy folyamat magyarázata magában foglalhatja a kritikus eseményeket és fordulópontokat, környezeti hatásokat és az elốre nem látott tényezóket, melyek befolyásolják az események menetét.

A szerzók a folyamatmodellek négy elméleti típusát különböztetik meg: életciklus-, evolúciós, dialektikus és teleológiai modell (Van de Ven, 1992; Van de Ven - Poole, 1995). Ezek a modellek alapvetôen eltéró logikára épülnek, bemutatva azt a mechanizmust, ami magyarázatot ad arra, hogy a megfigyelt események mié túnnek fel bizonyos fejlődéssorozatokban, speciális $\mathrm{k}$ rülmények vagy feltételek fennállása esetén.

Az életciklus-modell az entitás lineáris és elốre meghatározott fejlódését tételezi fel. A külsố környezet befolyást gyakorolhat ugyan a fejlődés menetére, azonban a fejlódés irányát a benne rejló logika diktálja.

- Az evolúciós modell a változat-kiválasztásmegtartás evolúciós fejlódésfolyamat mellet érvel. A változatok egyszerúen adottak, a kiválasztás a szúkös erőforrásokért vívott küzdelmen keresztül valósul meg, míg a megtartás a stabili-

tást szolgálja.

\section{VEZETÉSTUDOMÁNY}

- A dialektikus modell szerint a fejlódést az egymással konkuráló, a szervezeten belüli és kívüli célok és erók közötti hatalmi egyensúly periodikus módon jelentkezố zavarai idézik elố.

- A teleologikus modell a teleológiára, illetve arra a filozófiai tételre támaszkodik, amely szerin az entitások célorientáltak és adaptívak, a cél elérése érdekében cselekednek, és figyelemmel követik a fejlődést. Következésképpen a folyamat ,ismétlódó sorozata a célmeghatározásnak, végrehajtásnak, értékelésnek és a cél módosí-

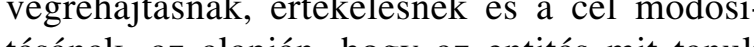


1995: 516 0). Hab́r a fejós de Ven - Poole, 19.5. 516. o.). Habár a fejlodés motorját a célok adjak, a teleológia elismeri a tevékenységekre gyakorolt környezeti hatásokat is. Az életciklusmodellel szemben a teleológia nem írja eló az események szükségszerú sorozatát, illetve nem részletezi, hogy a szervezetnek milyen utat kell követnie.

A tudományos munkákban ezen elméleti modellek gyes elemeinek különbözố kombinációi figyelhető́ek meg, és ritka a modellek tiszta formában történó elő́fordulása (Van de Ven, 1992). Van de Ven (1992) ugyanakkor szükségesnek tartja egy folyamat kutatása során az alkalmazott folyamatmodell tisztázását. Szem elốt tartva, hogy elméleti modelltípusokról van szó, jelen tanulmány a fejlődési folyamat teleológiai aspektusát veszi alapul, hiszen e nézôpont jellegzetességei összhangban állnak a tanulmányban képviselt nézóponttal: a nemzetköziesedési folyamat szubjektív módon célorientált, egyéni és kollektív tevékenységek sorozata és összefüggésrendszere egy speciális környezetben.

A teleológiai modellnek megfelelóen a célorientált folyamatok sorozatának megértésére törekszünk, am elósegíti vagy visszafogja egy cég nemzetközi előmenetelét. A nemzetköziesedésre mindenekelốtt a nemzetközi múveletekbe való bekapcsolódás időhöz kötöt folyamataként tekintïnk. Továbbá a nemzetköziesedés folya stratégiai folya egy strategiai folyanatnak tekintjük, melyet külső körvezerontist és belsôleg konzisztens motivátorok piacrá lés módjéban - a nemzetköziesedés a kulfoldi alkotva - nyilvául meg. Így tehát értel ezésinázatá

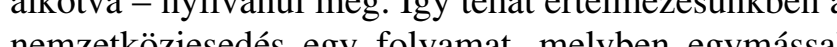
nemzetköziesedés egy folyamat, melyben egymással összekapcsolódó és integrált döntések és folyamatok egyesülnek a vállalat egyedi nemzetközi fejlódési mintaját megrajzolva. Jones-szal (Jones, 1999) egyetértve további feltételezésünk, hogy a nemzetközivé válás elválaszthatatlan része a cég általános növekedési és fejlődési folyamatának. 
A nemzetköziesedés egy összetett jelenség, melynek összefüggései nem csupán idốben változnak, hanem térben is. Következésképpen, a jelenség intézményi, kulturális környezetét magyarázó tényezóként, és nem határfeltételként kell szemlélni (Cheng 2007). Amin az a fentiekben kifejtésre került, az Uppsala-modellt szerzók a kontextus megváltozása miatt fogalmazták újra (Johanson - Vahlne, 2009). A kontextus közpon kezelése különösen fontos lehet a közép-kelet-európai átalakuló országokban kifejlődött vállalatok esetében, melyek nagyon eltérő fejlődési mintázatot mutató iizleti környezetben (Szelényi, 2004) tevékenykednek, belsố vállalati fejlódés (Peng - Heath, 1996; Whit ay - Czab́n, 1998; Peng, 2003) ́́s a globális; gazdáa ba való belépés küilönbözố fejlődési pályáit követik. Mivel az átán mányos antakió országok nem tekinthetok hagyokörnos anyanszagnak, fontos lehet e vállalatoknak a környezeti feltételekkel való kölcsönhatásainak tanulmányozása is. A második propozíció az alábbiak szerint fogalmazható meg:

P2: A nemzetköziesedés folyamatának vizsgálata ne választható el a kontextus alakulásának vizsoálatától.

\section{A kutatási modell}

A fentiekben részletezett propozíciókra és koncepcionális alapokra építve a vállalatok nemzetköziesedés folyamatának dinamikáját megragadó kutatási model az 1. ábra foglalja össze. 1. ábra

A vállalatok nemzetköziesedésének dinamikája - kutatási modell

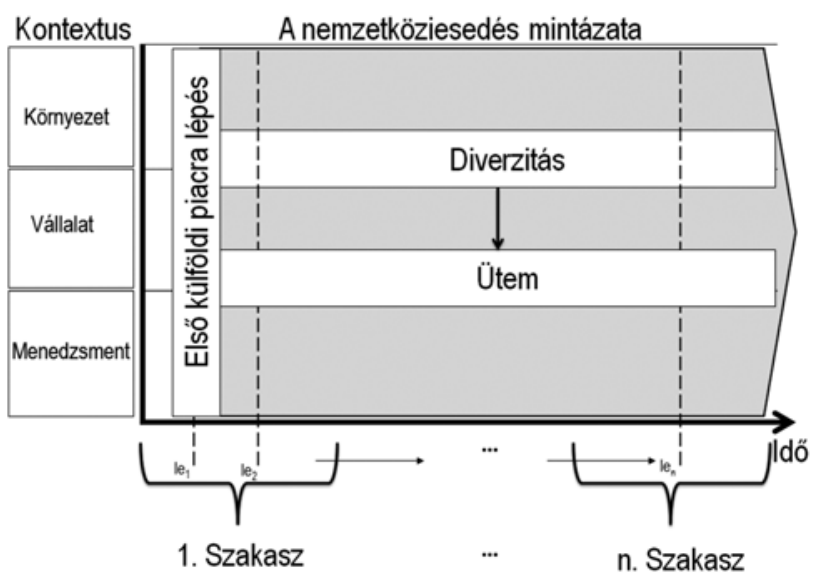

Tekintettel arra, hogy célunk a nemzetköziesedés dốben vizsgált dinamikájának leírása és megértése, hozzájárulva a nemzetköziesedés folyamatorientál, jelenségvezérelt szemléletének bővítéséhez, az idó modell elsődleges koncepcionális dimenziója. Az idó függvényében vizsgáljuk a nemzetköziesedés mintázatát, amelyet az idóben változó kontextus befolyásol.

A nemzetköziesedés mintázatát a nemzetközi piacra való kilépéstól vizsgáljuk - elsố külföldi piacra lépés -, ugyanakkor fontos lehet a piacra lépést megelózố időszak elemzése is, annak érdekében, hogy felfedjük, milyen körülmény (kontextus) vezetett el a nemzetközi piacra lépéshez és az alapítástól számítva mennyi idố telt el az első nemzetköziesedési eseményig $\left(\mathrm{Ie}_{1}\right)$. Jones és Coviello (2005) alapján minden olyan momentum amikor egy vállalat új országban jelenik meg vagy elhagyja azt, egy nemzetköziesési eseménykén (Ie) keiil az eäle nem kejo mint szun eleket pedig azon évek alkotják, amikor új vábi vábbi mintázatát a külơldi lokációban és a külföldi piacra lépés módjában történt változások adják, amelyet a modellben a diverzitás fogalommal jellemeztünk. A külföldi lokációban fontosnak tartjuk követni az országok számának változását és az adott ország távolságát. ${ }^{9}$ A piacra lépési módozatok (export, a szerződéses megoldások - licenc, franchise, stratégiai szövetség, közös vállalkozás - és külföldi leányvállalat - felvásárlás és zöldmezős beruházás -) követése esetünkben nem feltétlenül a külföldi piacon való elkötelezốćs méréćt szolgálja hanem a nemzettözhálózatfejlesztés logikájén fettérképezésát, ametó hálózatrejlesztés logikajanak felterképezését, amely nagymertékben kontextusfüggó (pl. a piacra lépés módját eroforások rendelkezésre állása, a piaci lehetóségek befolyásolhatjâk). Meg kell ugyanakkor említeni, hogy a nemzetköziesedési minta egyéb indikátorok segítségével is követhetô, mint például a befektetés nagysága (Johansson - Vahlne, 1990), a hozzáadott érték jellege és mértéke a tevékenységi értéklánc mentén (Kutschker - Baurle, 1997), a külföldi piacokhoz fúzódô kapcsolatok erőssége (pl. a vertikális integráció szintje, Johansson - Vahlne, 1990; Kutschker - Baurle, 1997). Tekintettel az adatok elérhetôségére és összehasonlíthatóságára, a lokációt és a belépés módját tartjuk a legkézenfekvő́bb elemzési egységnek. A nemzetköziesedés ïtemét a nemzetköziesedési események idôbeni alakulás adja, amelyet a kontexo mények idón hán mellett a nemzetkôziesedés divezitása is befolyásol-

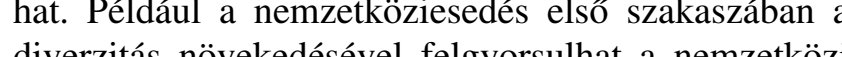
diverzitás növekedésével felgyorsulhat a nemzetközi terjeszkedés, egy bizonyos diverzitásszinten túl pedig akár le is lassulhat.

A belépés, diverzitás ütemkoncepciók mentén operacionalizált nemzetköziesedés domináns mintázatai alapján különböző fejlődési szakaszokat lehet meghatározni, amely a nemzetközi evolúció egy hosszabb idôtávot átfogó absztrakciós szintje.
A kontextus különböző szinteken alakítja a cég nemzetközivé válását. A nemzetköziesedés mintázata és kontextus közötti kapcsolat megteremtése érdekében különbözổ szinteken zajló eseményeket, tevékenységeket és a közöttük lévố kölcsönhatásokat követjük. Ily módon képesek vagyunk leírni és megérteni a nemzetközivé válás folyamata során kialakuló komplex kapcsolatrendszert. Három specifikus kontextuális szintet különböztetünk meg: a környezeti szint, a vállala szint és a döntéshozói szint.

- A környezeti szint a cég nemzetközivé válását befolyásoló globális/regionális, nemzeti és ipaági környezetre utal. A környezet adta lehetôsegek nagymértékben alakítják a nemzetköziesedés mintázatát

A vállalati szint esetében a cég nemzetköziesedésére hatással levő erőforrásokra és képességekre, a vállalati stratégiákra és teljesítményre, valamint a tevékenységek jellegzetességére kell figyelenmel lenni.

- A menedzsment szintje az egyéni döntéshozók olyan tulajdonságainak vizsgálatát teszi lehetővé, mint a nemzetköziesedéssel kapcsolatos attitűd, a nemzetközi piaci ismeretek és tapasztalatok, személyközi kapcsolatok.

Az idő figyelembevételével feltérképezett nemzetköziesedés az alábbi specifikus kutatási kérdések alapján vizsgálható

1. Mikor kezdeményezte a vállalat a nemzetközivé válás első eseményét, és mi befolyásolta az idôzítést? - elsó külföldi piacra lépés

2. Miként nőtt az országok száma és távolsága, valamint a belépési módok száma és skálája az idő́k során, és mi befolyásolta a mintázatot? diverzitás

3. A cég milyen gyorsan terjeszkedett a nemzetközi piacon, és mi befolyásolta a nemzetköziesedés ritmusát? - ütem

4. Milyen nemzetköziesedési szakaszok azonosíthatók az idố múlásával, és melyek azok a kontextuális feltételek, melyek a szakaszokat alakították? - szakaszok

\section{Összegzés}

A tanulmányban bemutatott kutatási modell empiriku példán való alkalmazása lehetôvé teszi a nemzetközivé válás cégspecifikus folyamatának feltárását és megértését, térbeli és időbeli összefüggéseinek feltérképezését. A javasolt modell feltáró kutatáshoz, a vállalatok nemzetköziesedésének a leírására és megértésére al- kalmas magatartásorientált modell. Tesztelésre alkalas összefüggéseket nem ír elô, hanem lehetôséget ad leváns összefüggések feltárására. A modell legfóbb rőssége, hogy lehetôséget nyújt a nemzetköziesedést alakító kontextus longitudinális vizsgálatára. Legfóbb gyengesége, hogy empirikus alkalmazása módszertanilag összetett, a többéves idôhorizont eseményeinek feltárása és elemzése pedig időigényes. Természetüknél fogva a folyamatjelenségek, mint a nemzetköziesedés is, rendkívül összetettek, következésképpen a folyamatvizsgálathoz szükséges adatok eklektikusak, és nehéz (1999). A mlektikusak, és nehéz

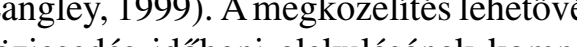
ex mata tex kapcsolatrendszert eredményez. Ahhoz, hogy bizonyos eredményeket - mint pélaán a kulonbözó kontextuális szintek aszinkron hatásainak elemzése egy vállalat nemzetkoziesedésének sebességére - tovább elemezzünk, és hogy precízebb eredményekre jussunk, mindenképp szükséges egy kezelhető számú tényezőcsoport kiválasztása, melyeket aztán nagymintás elemzésnek is alávethetünk. Mindazonáltal a nemzetköziesedés mintázatának kontextusba ágyazott feltérképezését követően lehetốségünk lehet a nemzetköziesedés releváns indikátorainak megragadására és a közöttiik lévő́ összefüggések (hipotézisek) vizsgálatára alkalmas specifikus modellek kifejlesztésére.

\section{Lábjegyzet}

A szerző köszönetét nyilvánítja Dr. Czakó Erzsébetnek a tanulmány továbbfejleszztéséhez tett értékes javaslataiért

zetközi kereskedelem és szakosodás elméleti tételéi a a nemdelempolitika eszközeire, módszereire vonatkozó ismeretek, a nemzetközi pénzforgalom és tökeáramlás problematikája, valamint a fizetési mérleggel kapcsolatos kérdések tartoznak (Szentes, 1995: 4. old).

A vizsgálati területek között ugyanakkor nem húzható éles határ. Pl. befektetési fejilodéspálya elmélet (Investment Development
Path Theory) (Dunning 1982. Dunning - Narula 1996), repüló Path Theory) (Dunning, 1982; Dunning - Narula, 1996), ,repülö ludak"
2000 ).
4 Pl. piacihat

Pl. piacihatalom-megközelités (market power approach) (Hymer, 1960), a multinacionális vállalatok tranzakciós költségek (Hennart, 1982, 1988, 2001) megközelitése és az internalizációs elmélet (Buckley - Casson, 1976; Rugman, 1980, 1981), az eklektikus paradigma (Dunning, 1980, 1981)

Ide tartoznak például Chandler (1962), Stopford és Wells (1972), Bartlett és Ghoshal (1988, 1989), Hamel és Prahalad (1989), kái, melyek a teljesség igénye nélküli felsorolásban a úttörö munstratégia-struktúra paradigma, a globális integráció-lokális válaszképesség dilemma az anyavállalat-leányvállalat közötti kapcsolat menedzselésének a kérdéseivel foglalkoznak 'Atanulmány terjedelmi okok miatta vállalatoknemzetköziesedése 
elméleti modelljeinek rövid és nem teljes körü összefoglalását dja. Részletesebb, a hazai vállalatok nemzetköziesedésének vonatkozásait is tárgyaló, magyar nyelvủ szakirodalmi áttekintés- Czakó (2007), Czakó (2010), Antalóczy és Sass (2011)

A piaci elköteleződést a szerzők a piacra lépési módozatokban és "

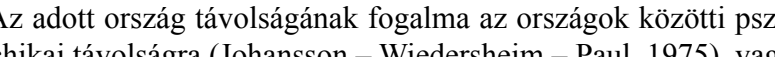
és a gazdasági (E) távolságra utal, melyet Ghemawat a CAGE keretben foglal össze (Ghemawat, 2001).

\section{Felhasznált irodalom}

Antalóczy K. - Éltetố A. (2002): Magyar vállalatok

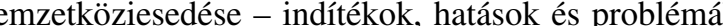
Közgazdasági Szemle, XLIX évf., február

Antalóczy K. - Sass M. (2011): Kis- és közepes méretu vallalatok nemzetköziesedése - elmélet és empíri Külgazdaság, LV. évf. szeptember-október, p. 22-33.

Bartlett, Ch. - Ghoshal, S. (1988): Organizing for Worldwide Effectiveness. The Transnational Solution. Californ Management Review, Fall

Bartlett, Ch. - Ghoshal, S. (1989): Managing across borders: The Transnational Solution. Boston, MA: Harvar Business Scool Press

Bartlett, Ch. - Ghoshal, S. (2002): The transnational and beyond: reflections and perspectives at the millennium. in: Hitt, M.A. - Cheng, J.L.C. (Eds.): Managing Transnational Firms: Resources, Market Entry and Strategic Alliances. Advances in Internation Management Series. Oxford: Elsevier/JAI, p. 3-36.

Beamish, P. (1990): The Internationalisation Process for Smaller Ontario Firms: A Research Agenda. in: Rugman, - International Business Research for the Twenty-First Century: Canada's New Research Agenda. Greenwich: JAI Press Inc., p. 77-92. Entrepreneurship. Entrepreneurship Theory and Practice, 23(3), p. 29-45.

Buckley, P. - Casson, M. (1976): The Future of Multinationa

Buckley, P. - Lessard, D. (2005): Regaining the edge for international business research. Journal of International Business Studies, 36(6)

Burrell, G. - Morgan, G. (1979): Sociological Paradigm and Organizational Analysis: Elements of the Sociology of Corporate Life. London: Heinemann

Center for Process Studies (2007): http://www.ctr4process. org/about/process/ letöltve 23.06.2007.

Chandler A (1962): Strategy and Structure. Cambridge, MA: MIT Pres Befelé irányuló nemzetköziesedésnek tekinthető például a termék- vagy technológiaimport, a nemzetközi licencvásárlás, a befelé irányuló franchise szerződes. közelebbről a kulturális (C), az admnisztratív (A), a földrajzi (G) A. M. (ed.): Research in Global Strategic Management

Brazeal, D. - Herbert, T. (1999): The Genesis of Enterprise. London: Macmillan

Cheng, J. (2007): Critical issues in international management research: an agenda for future advancement. European Journal of International Management, 1(1/2)

Chia, R. - Langley, A. (2004): The First Organization Studies Summer Workshop: Theorizing Process in Organizational Resarch. call for papers, Organization Studies, 25(8)

Covin, J.G. - Slevin, D.P. (1991): A Conceptual Model of Entrepreneurship as Firm Behavior. Entrepreneuship Theory and Practice, 16(1), p. 7-25.

Cyert, R.D. - March, J.G. (1963): A Behavior Theory of the Firm. Englewood Cliffs, NJ: Prentice-Hall

Gáspár J. - Czakó E. (2007): Vállalatok nemzetközivé válása és a versenyképesség. in: Könczöl Erzsébet (szerk): Vállalatí stratégia. Budapest: Alinea Kiadó, 231-278. o. Czakó E. (2010): A nemzetközi üzleti gazdaságtan min elméleti háttér. in: Czakó Erzsébet - Reszegi László (szerk): Nemzetközi vállalatgazdaságtan. Budapest: Alinea Kiadó, 31-62. o.

Doz, Y. - Prahalad, C.K. (1991): Managing DMNCs: A search for a new paradigm. Strategic Managemen Journal, 12, p. 145-164.

Dunning, J.H. (1980): Toward an Eclectic Theory of International Production: Some Empirical Tests. Journal of International Business Studies, Vol. 11, Issue 1

Dunning, J.H. (1981): International Production and the Multinational Entreprise. London: George Allen \& Unwin Dunning, J.H. (1982): Explaining the International Direct Investment Position of Countries: Towards a Dynamic or Developmental Approach. in: J. Black and J.H. Dunning (eds.): International Capital Movements, London: Macmillan

Dunning, J.H. (1995): Reappraising the Eclectic Paradigm in an Age of Alliance Capitalism. Journal of International Business Studies, 26(3)

Dunning, J.H. - Narula, R. (1996): The Investment Development Path Revisited: Some Emerging Issues. in: Dunning, J. H. - Narula, R. (Eds): Foreign Direc Investment and Governments: Catalysts for Economic Restructuring. London: Routledge

Forsgren, M. - Johanson, J. (1992): Managing Internationalization in Business Networks. in: M. Forsgren - J. Johanson (ed.): Managing Networks in International Business. Philadelphia, Amsterdam: Gordon and Breach, p. 1-15.

Ghemawat, P. (2001): Distance Still Matters: The Hard Reality of Global Expansion. Harvard Business Review, September-October

Hamel, G. - Prahalad, C.K. (1989): Strategic Intent. Harvard Business Review, 89(3), p. 63-76.

Hashai, N. - Almor, T. (2004): Gradually internationalizing 'born global' firms: an oxymoron? International Business Review, 13, p. 465-483.

Hempel, C.G. (1965): Aspects of Scientific Explanation. New York: The Free Press

VEZETÉSTUDOMÁNY
Hennart, J. - F. (1982): A Theory of Multinational Enterprise. Ann Arbor, MI: University of Michigan Press

Hennart, J. - F. (1988): A Transaction Costs Theory of Equity Joint Ventures. Strategic Management Journal, 9. p. 361-74.

Hennart, J. - F. (2001): Theories of Multinational Enterprise. in: A. M. Rugman - T. A. Brewer (eds.): The Oxford Handbook of International Business. Oxford: Oxford

Hymer, S. (1960): The International Operations of Nationa Firms: a Study of Direct Foreign Investment. Ph.D. hesis, published in 1976. Cambridge, Mass.: MIT

Hurmerinta-Peltomäki, L. (2003): Time and Internationalization. Theoretical Challenges Set by Rapid Internationalization. Journal Entrepreneurship, 1., p. 217-236.

Incze E. (2005): Feltörekvő́ multinacionálisok - a magya vállalatok nemzetköziesedésének folyamata. Értekez ervezet, kézirat, Budapest: Budapesti Corvinus Egyetem

Incze E. (2010): Stratégiai menedzsment a globális piacon. in: Balaton Károly - Hortoványi Lilla - Incze Emma Laczkó Márk - SzabóZ Zsolt Roland - Tari Ernő́: Stratégia menedzsment. Budapest: Aula Kiadó, p. 90-126.

Johanson, J. - Mattsson, L.G. (1986): International Marketing and Internationalization Process - A Network Approach. in: Paliwoda, S. - Turnbull, P. (eds.): Research in International Marketing. London: Croom Helm

Johanson, J. - Mattsson, L.G. (1988): Internationalization in Industrial Systems - a Network approach. in: N. Hood J. - E. Vahlne (eds.): Strategies in Global Competition. London, New York, Sydney: Croom-Helm, p. 287-314.

Johanson, J. - Mattsson, L.G. (1992): Network Positions and Strategic Action - An Analytical Framework. in: Axelsson, B. - Easton, G. (eds.): Industrial Networks: A New View of Reality. London: Routledge, p. 205-217.

Johanson, J. - Vahlne, J.E. (1977): The Internationalization rocess of the Firm: AModel of Knowledge Development and Increasing Foreign Market Commitments. Journal of International Business Studies, Vol. 8, No. 1

Johanson, J. - Vahlne, J.E. (1990): The Mechanism of Internationalisate $J$. Vol. 7 , No. 4

Johanson, J. - Vahlne, J.E. (2009): The Uppsala Internationalization Process Model Revisited - From liability of foreignness to liability of outsidership. Journal of International Business Studies, 40

Jones, M.V. (1999): The Internationalization of Small High Technology Firms. Journal of International Marketing, $7(4)$, p. $15-41$

Jones, M.V. (2001): First Steps in Internationalisation: Concepts and Evidence from a Sample of Small High Technology Firms. Journal of International Managemen 7(3), p. 191-210.
Jones, M.V.Coviello, N.E. (2002):ATime-BasedContingency Model of Entrepreneurial Internationalization Behaviour. Working Paper 2002/12, Haskayne School of Business Jones, M.V. - Coviello, N.E. (2005): Internationalization conceptualising an entrepreneurial process of behaviour in time. Jounnal of International Business Studies, 36(3) p. 284-303.

indleberger, C.P. (1969): American Business Abroad: Six Essays on Direct Investment 1-36, New Haven: Yale University Press

ima, K. (1978): Direct Foreign Investment: A Japanese Model of Multinational Business Operations. London: Croom-Helm

Kojima, K. (2000): The "flying geese" model of Asian economic development: origin, theoretical extensions, and regional policy implications. Journal or Asian Economics, 11, p. 375-401.

Kutschker, M. et al. (1997): International Evolution, International Episodes, and International Epochs - Implications for Managing Internationalization. Management International Review, 37(2)

Langley, A. (1999): Strategies for theorizing from process data. Academy of Management Review, 24(4)

Lumpkin, G.T. - Dess, G.G. (1996): Clarifying the Entrepreneurial Orientation Construct and Linking it to Performance. Academy of Management Review, 21(1), p. 135-172. Antarinen, R. et al. (1994): Globalization and SME. Helsinki: Ministry of Trade and Industry

Malnight, Th. (1995): Globalization of an Ethnocentric Firm: An Evolutionary Perspective. Strategic Management Journal, 16. p. 119-14

Mathews, J.A. (2002): Dragon Multinational. A New Mode for Global Growth. Oxford: Oxford University Press

Dougall, et al. (2003): A Comparison of International and Domestic New Ventures. Journal of International Entrepreneurship, 1(1), p. 59-82.

CcDougall, P. - Oviatt, B. (2003): Some fundamental issues in international entrepreneurship. July 2003 (http://www.usasbe.org/knowledge/whitepapers/ mcdougall2003.pdf)

eelin, L. (1992): Internationalisation as a Strategy Process Strategic Management Journal, 13, p. 99-118.

intzberg, H. (1987): The Strategy Concept: The Five P's for Strategy. California Management Review, 30, p. 11-23. Oviatt, B. - McDougall, P. (1994): Toward a Theory of International Business Studies. Journal of International Business Studies, Vol. 25, Issue 1

Ozawa, T. (1979): Multinationalism, Japanese Style: The Princeton University Press

Ozawa, T. (2000): The 'Flying-Geese' Paradigm: Toward a Co-evolutionary Theory of MNC-Assisted Growth. in: K. Fatemi (ed.): The New World Order: Internationalism, Regionalism and the Multinational Corporations. New York, NY: Pergamon, p. 209-223. 
Pentland, B. (1999): Building process theory with narrative: from description to explanation. Academy of Management Review, 24(4)

Perrow, Ch. (1997): Szervezetszociológia (Complex Organisations: a critical essay). Budapest: Osiris Kiadó

Prahalad, C.K. - Hamel, G. (1990): Core Competence of the Corporation. Harvard Business Review, May-June, p. 79-91.

Reuber, A. - Fischer, E. (1997): The influence of the management team's international experience on internationalization behaviour. Journal of International Business Studies, 28(4)

Peng, M. - Heath, P.S. (1996): The Growth of the Firm in Planned Economies in Transition: Institutions, Organizations, and Strategic Choice. Academy of Management Review, Vol. 21, Issue 2

Peng, M. (2000): Business Strategies in Transition Economies. Thousand Oaks, CA: Sage Publications

Peng, M. (2003): Institutional Transitions and Strategic Choices. Academy of Management Review, Vol. 28, No. 2

Penrose, E. (1959): The Theory of the Growth of the Firm. London: Basil Blackwell

Reid, S. (1983): Firm Internationalization, Transaction Costs and Strategic Choice. International Marketing Review, Vol. 1, No. 2

Rugman, A.M. (1980): Internalization as a General Theory of Foreign Direct Investment: a reappraisal of the literature. Weltwirtschaftliches Archiv, 116, 2

Rugman, A.M. (1981): Inside the Multinationals: the Economics of Internal Markets. London, New York, Sydney: Croom-Helm

Shane, S. - Venkataraman, S. (2000): The Promise of Entrepreneurship as a Field of Research. Academy of Management Review, 25(1), p. 217-226.

Stopford, J.M. - Wells, L.T. (1972): Managing the Multinational Enterprise. New York: Basic Books

Szentes T. (1995): A világgazdaságtan elméleti és módszertani alapjai. Budapest: Aula Kiadó

Sullivan, D. (1998): Cognitive Tendencies in International Business Research: Implications of a "Narrow Vision". Journal of International Business Studies, Vol. 29, No. 4
Szelényi I. (2004): Kapitalizmusok, szocializmusok után (Forms of capitalism after forms of socialism). Egyenlító, Társadalomkritikai és kulturális folyóirat, 2. sz.

Turnbull, P. (1987): A Challange to the Stage Theory of the Internationalization Process. in: Reid, S. - Rosson, P. (eds.): Managing Export Entry and Expansion. New York: Praeger

Vernon, $R$. (1966): International Investment and International Trade in the Product Cycle. Quarterly Journal of Economics, 80

Van de Ven, A.H. - Huber, G.P. (1990): Longitudinal field research methods for studying process of organizational change. Organization Science, 1, p. 213-219.

Van de Ven, A.H. - Poole, M.S. (1995): Explaining Development and Change in Organizations. Academy of Management Review, 20(3), p. 510-540.

Van de Ven, A. - Egelman, R. (2004): Event- and outcomedriven explanations of entrepreneurship. Journal of Business Venturing, 19(3)

Van de Ven, A.H. - Poole, M.S. (2005): Alternative Approaches for Studying Organizational Change. Organization Studies, 26(9), p. 1377-1404.

Welch, L. - Luostarinen, R. (1988): Internationalization: evolution of a concept. Journal of General Management, 14(2), p. 34-55.

Welch, L. - Loustarinen, R. (1993): Inward and outward connections in internationalization. Journal of International Marketing, 1(1), p. 46-58.

Whitley, R. - Czabán L. (1998): Institutional Transformation and Enterprise Change in an Emergent Capitalist Economy: The Case of Hungary. Organization Studies, Vol. 19, Issue 2

von Wright, G.H. (1971/2004): Explanation and Understanding. Cornell University Press

Zahra, S.A. (1993): A Conceptual Model of Enterpreneurship as Firm Behaviour: A Critique and Extension. Enterpreneurhip: Theory and Practice, 17(4), p. 5-30.

Zahra, S.A. - Santeri, J.K. - Yu, J.F. (2005): Cognition and international entrepreneurship: implications for research on international opportunity recognition and exploitation. International Business Review, Vol. 14, p. 129-46. 